\title{
D/H FRACTIONATION OF COEXISTING BIOTITE AND HORNBLENDE IN TABITO COMPOSITE MASS, ABUKUMA PLATEAU, JAPAN
}

\author{
Y. KURODA*, T. SUZUOKI ${ }^{* *}$, S. MATSUO*** and H. TANAKA****
}

\begin{abstract}
Tabito composite mass consists of two groups of intrusions, e.g. the older (Myojin-ishi. quartz-diorite and gabbro) and the younger (Komuro quartz-diorite and Iritabyuto granodiorite). The equilibrium relationship is recognized on $\delta \mathrm{D}-\mathrm{X}_{\mathrm{F} \text { a }}$ plots of coexisting biotitehomblende pairs. $8 \mathrm{D}$ value of water in magma coexisted with biotite and hornblende in the younger group is estimated to be almost similar to that for the granitic masses in the Kitakami mountaineous district $(-29$ to $-37 \%$ ), while that in the older group is clearly lighter $(-40$ to $-55 \%$ ).
\end{abstract}

\section{INTRODUCTION}

Kuroda et al. (1974) found that coexisting pairs of biotite and hornblende from the Cretaceous granitic rocks in the southern Kitakami mountaineous district are in equilibrium with respect to hydrogen isotope exchange. On this basis $\delta \mathrm{D}$ value of the ambient water equilibrated with biotite and hornblende in these rock masses was estimated to be -29 to $-37 \%$. Further investigation on the Cretaceous granites in the northern Kitakami mountaineous district revealed that $\delta \mathrm{D}$ values of most of biotite were slightly higher than those of coexisting hornblende. Although this fact was accounted for the incomplete quenching of biotite-water equilibrium, $\delta \mathrm{D}$ value of the water in magma of the granites was estimated to be almost similar to that of the southern Kitakami granitic rocks (Kuroda et al. 1975 a).

On the other hand, the $\delta \mathrm{D}$ value of the water in the Paleogene granitic magma of the Miyazu mass in Southwest Japan was estimated to be -60 to $-65 \%$, which is quite different from that of the Kitakami mountaineous district Kuroda et al. 1975 b).

In the Abukuma plateau there are many granitic masses as in the Kitakami mountaineous district. Those of both districts have been called Cretaceous granites in northeast Japan. Their $\mathrm{K}-\mathrm{Ar}$ ages are the same each other, ranging 90 to $110 \mathrm{~m}$. y. (Kawano and Ueda 1965 a, b). Our interest extended to investigate $\mathrm{D} / \mathrm{H}$ fractionation of coexisting biatite and homblende and to estimate $\delta \mathrm{D}$ value of water in magma of the Abukuma granitic masses in relation to the Kitakami granitic masses.

\section{Outline of Geology}

In the Gosaisho-Takanuki district of the Abukuma plateau there are various kinds of granitic rocks. Among them the

* Geological Department, Shinshu University, Matsumoto,

** Marine Department, Japan Meteorological Agency, Tokyo,

*** Department of Chemistry, Tokyo Institute of Technology, Tokyo,

**** Department of Geology, Yamagata University, Yamagata. (Manuscript received October 31, 1975) 
Tabito mass has a relatively simple construction and is situated at the boundary of Area I and II of the Gosaisho-Takanuki metamorphic rocks (Kano et al. 1973). RbSr age for biotite of the mass was reported to be 92 m.y. (Ueno 1968) and Rb-Sr isochron age of whole rocks was given to be $150 \mathrm{~m} . y$. (Maruyama 1972).

Tabito composite mass is composed of four rock types with the following succession of intrusion; Myōjin-ishi quartzdiorite, gabbro, Komuro quartz-diorite and Iritabyūto granodiorite (Fig. 1) (Tanaka 1974).

Myōjin-ishi quartz-diorite is composed of biotite, hornblende, plagioclase and quartz, and often contains cummingtonite and clinopyroxene. K-feldspar is found in an about half of the collected specimens. Gabbro has a wide variation in constituent minerals and texture. It often shows cortlanditic texture and composition, but in any facies biotite and homblende are included. Komuro quartz-diorite consists of biotite, plagioclase and quartz. Hornblende is often found, but K-feldspar, cummingtonite, clinopyroxene and orthopyroxene are never found. Iritabyruto granodiorite, which is the main facies of the Tabito mass, is composed of biotite, hornblende, plagioclase, K-feldspar and quartz. In the Iritabyrīto granodiorite dark inclusions (several $\mathrm{cm}$ to several $m$ in size) of various shapes are found and they are similar to the Koumro quartz-diorite in petrographical characters. The intrusion of Iritabyut to granodionite is followed by the intrusion of aplite and pegmatite.

\section{Results AND Drscussion}

Three pairs of hornblende and biotite from Myōjin-ishi quartz-diorite, a pair from gabbro, three pairs from Komuro quartzdiorite, two pairs from Iritabyūto granadiorite, two of biotite from Iritabyūto granodiorite and aplite, and three pairs from dark inclusions were separated and analyzed (Tanaka 1975). The locality of these specimens is shown in Fig. 1 and the analytical result is listed in Table 1.

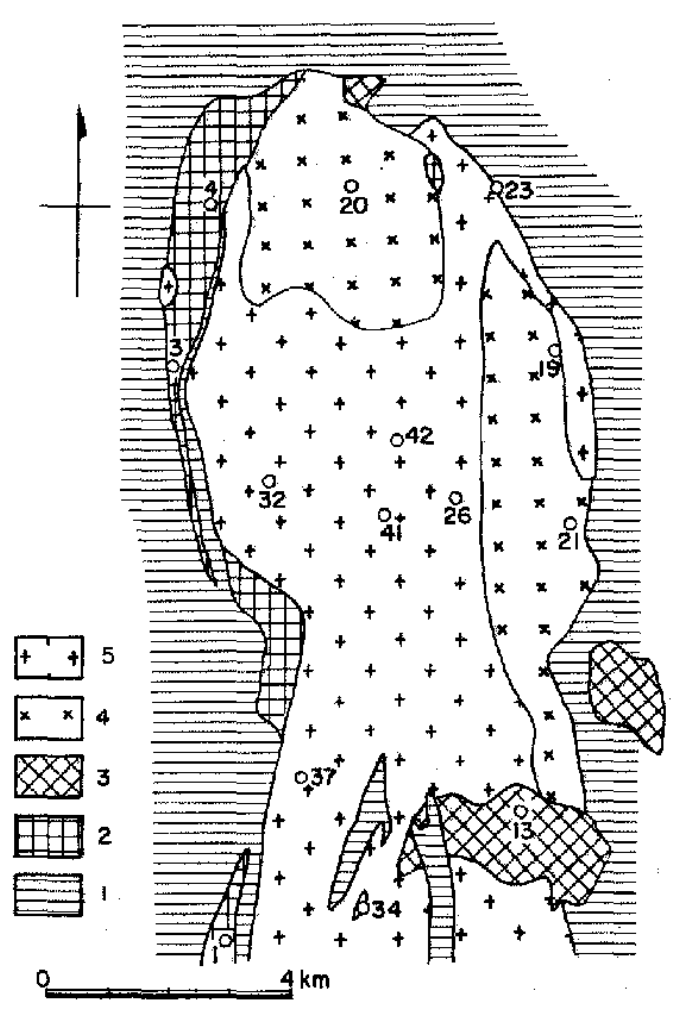

Fig. 1. Geological sketch map and locality of specimens studied.

1: country metamorphic rocks, 2: Myōjin-ishi quartz-diorite, 3: gabbro, 4: Komuro quartzdiorite, 5: Iritabyüto granodiorite. Numbers are the same as those in Table 1.

As seen in tie-lines on $\delta \mathrm{D}-\mathrm{X}_{\mathrm{F}}$ plots in Fig. 2, all the mineral pairs except No. 3 show nearly equilibrium relationship with respect to $\mathrm{D} / \mathrm{H}$ fractionation given by Suzuoki and Epstein $(1970,1972)$, as was previously found in southern Kitakami mountaineous district (Kuroda et al. 1974). 
Table 1. Analytical results and pertinent chemical informations of biotite and hornblende from the Tabito composite mass.

\begin{tabular}{|c|c|c|c|c|c|c|c|}
\hline & \multirow{2}{*}{$\begin{array}{l}\mathrm{SiO}_{2} \% \\
\text { w.r. }\end{array}$} & \multicolumn{3}{|c|}{ biotite } & \multicolumn{3}{|c|}{ hornblende } \\
\hline & & $\begin{array}{l}\mathrm{H}_{2} \mathrm{O} \\
\text { wt. } \%\end{array}$ & ${ }^{6 \mathrm{D}}$ & $\mathrm{x}_{\mathrm{Fe}}$ & $\begin{array}{l}\mathrm{H}_{2} \mathrm{O} \\
\mathrm{t.} \%\end{array}$ & $\delta \mathrm{D}$ & $\mathrm{X}_{\mathrm{Fe}}$ \\
\hline No.1 & 54.61 & 3.70 & -84.7 & 0.50 & 2.09 & -77.6 & 0.43 \\
\hline 3 & 55.53 & 3.83 & -66.2 & 0.45 & 1.96 & -66.2 & 0.38 \\
\hline 4 & 56.82 & 3.15 & -74.0 & 0.49 & 1.85 & -63.1 & 0.44 \\
\hline 13 & 49.74 & 3.85 & -73.9 & 0.49 & 1.95 & -71.0 & 0.45 \\
\hline 19 & 55.98 & 3.70 & -63.4 & 0.45 & 2.17 & -55.8 & 0.38 \\
\hline 20 & 56.76 & 3.38 & -60.7 & 0.51 & 1.99 & -49.7 & 0.45 \\
\hline 21 & 58.07 & 4.09 & -68.8 & 0.53 & 2.10 & -64.1 & 0.48 \\
\hline 23 & 59.92 & 4.53 & -74.4 & 0.52 & 1.91 & -73.1 & 0.49 \\
\hline 26 & 63.98 & 3.11 & -70.5 & 0.57 & 1.79 & -65.1 & 0.52 \\
\hline 32 & 69.38 & 3.44 & -70.3 & 0.57 & & & \\
\hline 34 & 71.60 & 4.61 & -72.4 & 0.60 & & & \\
\hline 37 & 46.98 & 4.12 & -71.5 & 0.50 & 2.03 & -51.9 & 0.48 \\
\hline 41 & 61.97 & 3.31 & -72.2 & 0.57 & 1.88 & -62.3 & 0.53 \\
\hline 42 & 55.56 & 3.40 & -66.0 & 0.52 & 1.96 & -60.0 & 0.48 \\
\hline
\end{tabular}

Nos. 1: 7281409 (Myöjin-ishi), 3: 7272011 (Myôjin-ishi), 4: 7272613 (Myöjin-ishi), 13: 80204 (gabbro), 19: 7272216 (Komuro), 20: 7272315 (Komuro), 21: 51505 (Komuro), 23: 7272307 (Iritabyūto), 26: 51506 (Iritabyūto), 32: 72017 (Iritabyūto), 34: 7281506A (aplite), 37 : $7281511 \mathrm{~A}$ (dark inclusion), 41:7331402B (dark inclusion), 42: 7372404B (dark inclusion).

The tie-lines of biotite and hornblende pairs observed are comparatively parallel to the equilibrium line or show slight shift

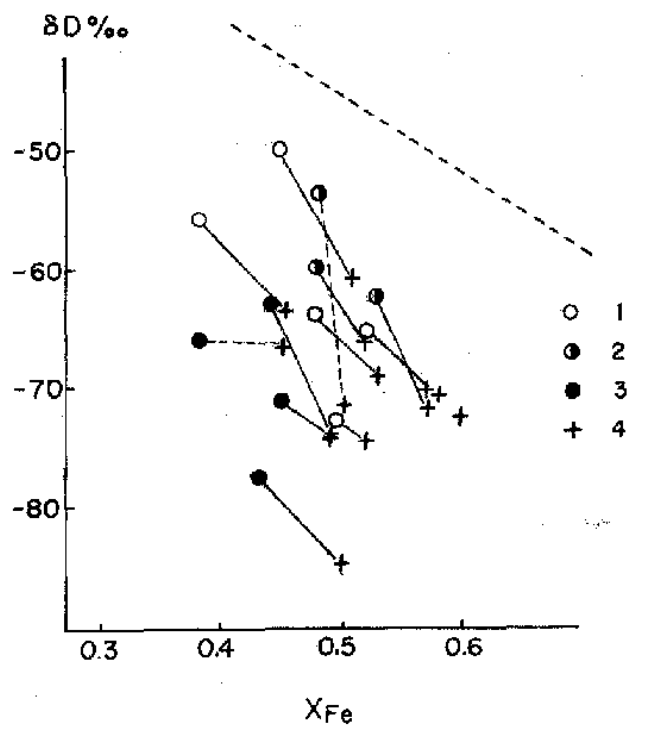

toward relative depletion of deuterium in biotite. The latter case can be reasonablly expected as a result of crystallization of biotite in later stage (lower temperature) than that of hornblende.

However, specimens of Nos. 3 and 37 (Table 1) are far from equilibrium relationship. These two examples can be attributed to the locality of No. 3 being at the very contact with country metamorphic rocks and the xenolithic occurrence for No. 37.

As reported by Tanaka (1974), the main

Fig. 2. Relationship of $\delta \mathrm{D}$ and $\mathrm{X}_{\mathrm{Fe}}$ of biotites and hornblendes.

1: hornblendes from Komuro quartz-diorite and Iritabyüto granodiorite, 2: hornblendes from daris inclusions, 3: hornblendes from Myōjin-ishi quartzdiorite and gabbro, 4 : biotites.

Broken line is Suzuoki-Epstein's experimental line (see Kuroda et al. 1975a). 
facies of the Tabito mass is Iritabyunto granodiorite. The tie-line of pairs in Iritabyūto mass is apparently in low $\delta \mathrm{D}$ range of Komuro mass and/or high $8 \mathrm{D}$ range of Myōjin-ishi quartz-diorite. As seen in Fig. 2, the $\delta \mathrm{D}$ of pair of specimen No. 23 is almost the same as $\delta \mathrm{D}$ of biotites from Nos. 34 and 32 which are separated from aplite and biotite-granite in this mass. On this basis, it can be rather inferred that the pairs of Iritabyūto granodiorite were equilibrated under comparatively low temperature with the same water as that of Komuro quartz-diorite.

Regarding the tie-line of pairs from dark inclusions in Iritabyũto granodiorite, the hornblendes are found to be the same region as those of Komuro quartz-diorite, while biotites are in the same region as those of Iritabyüto granodiorite. This finding is quite consistent to petrological similarity in Komuro quartz-diorite and dark inclusion pointed by Tanaka (1974). On the other hand, biotite could be relatively depleted in its deuterium content as a result of reequilibration of these inclusion with the host rock (Iritabyūto granodiorite) after their xenolithic situation was attained, when it is taken into account that the biotite is subject to follow the change in ambient chemical and thermal condition.

There is no petrological evidence to indicate definitely a difference in temperature of formation among these rocks (Iritabyūto, Myōjin-ishi and gabbro). Providing that the highest temperature of formation of these rocks is the same as that of Kitakami granitic masses, $\delta \mathrm{D}$ of the water in magma of Komuro and Iritabyūto rocks can be estimated to be -29 to $-37 \%$ which is fairly agreed with that of Kitakami masses, and the formation temperature of biotite and hornblende in Iritabyūto rocks can be also estimated to be as low as $450 \sim$ $550^{\circ} \mathrm{C}$.

On the other hand, as seen in Fig. 2, the observed over-all range of $8 \mathrm{D}$ variation for hornblendes is too large to attribute only to the variability in temperature of equilibration with an ambient water with same $8 \mathrm{D}$. Providing also the same formation temperature as Komuro quartz-diorite $\delta \mathrm{D}$ of the water in magma of Myōjin-ishi quartz-dionite and gabbro can be estimated to be -43 to $-51 \%$.

The result of $\mathrm{D} / \mathrm{H}$ fractionation study on Tabito composite mass presented here shows that $\delta \mathrm{D}$ of coexisting water in crystallization process of the older rocks Myojin-ishi quartz-dionite and gabbro is lower than that of younger rocks - Iritabyüto granodiorite and Komuro quartzdiorite of Cretaceous age.

\section{REFERENGES}

Kano, H. et al. (1973), Geology of the Takanuki district. Quadrangle Ser., 1:50,000, Geol. Surv. Japan, in Japanese with English abstract.

Kawano, Y. and Ueda, Y. (1965a), K-A dating on the igneous rocks in Japan (II) - Granitic rocks in Kitakami massif. - Jour. Japan. Assoc. Min. Pet. Econ. Geol., 53, 143-154, in Japanese with English abstract.

(1965 b), K-A dating on the igneous rocks in Japan (III) - Granitic rocks in Abukuma massif-. Jour. Japan. Assoc. Min. Pet. Econ. Geol., 54, 162-172, in Japanese with English abstract.

Kuroda, Y., Suzuoki, T., Matsuo, S. and Kanisawa, S. (1974), D/H fractionation of coexisting biotite and hornblende in some granitic rock masses. Jour. Japan. Assoc. Min. Pet. Econ. Geol., 69, 95-102.

(1975 a), D/H fractionation of coexisting biotite and hornblende in some granitic rock masses-Supplement. Jour. Japan. Assoc. Min. Pet. Econ. Geol., 70, 352-362.

Kuroda, Y., Kinugawa, T., Suzuoki, 'T. and Matsuo, S. (1975 b) Origin of the hornblendites in the Ōeyama (Komori) ultramafic body in view of hydrogen isotope study. Geoch. Jour., 9, 
$173-176$.

Maruyama, T. (1972), On the age of the whole rock $\mathrm{Rb}-\mathrm{Sr}$ isochron method in the GosaishoTakanuki district. Kibanganmi, 3, 14-20, in Japanese.

Suzuoki, T. and Epstein, S. (1970), Hydrogen isotope fractionation between OH-bearing silicate minerals and water. Publications of the Division of Geological and Planetary Sciences, California Institute of Technology, Contribution No. 1921 (in preprint form) (1972), Partition of hydrogen isotopes between hydrated silicate minerals and water.
Chikyukagaku, 5, 38-44, in Japanese.

Tanaka, H. (1974), On the Tabito composite mass in the Abukuma plateau. Jour. Japan. Assoc. Min. Pet. Econ. Geol., 69, 18-31, in Japanese with English abstract.

(1975), Magnesium-iron distribution in coexisting biotite and hornblende from granitic rocks. Jour. Japan. Assoc. Min. Pet. Econ. Geol., 70, 118-124

Ueno, N. (1968) Rb-Sr isotopic studies on granitic rocks and metamorphic rocks in the Ryōke, Abukuma and Hida metamorphic belts, Central Japan. Tokyo Univ., Docter thesis.

\section{阿武隈山地，田人複合岩体中の共存する黒雲母と角閃石の $\mathrm{D} / \mathrm{H}$}

\footnotetext{
黒田 声益·鈴置 哲朗・淞尾 禎士 - 田中 久雄

田人複合岩体は明神石石英閔線岩（1），は九れい岩 (2)，小室石烡閃緑岩 (3)、入旅人花崗閅緑岩（4）の4 つの岩相汃らなる。其存する黒零拉, 角閏石の $\mathrm{D} / \mathrm{H}$ 加

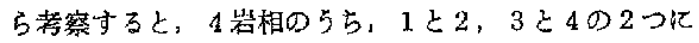
区分され，後者はぼ完全な平衡型で，そのマグマの水

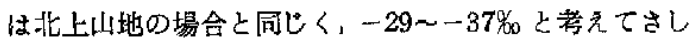

場合のマグマの水は $-43 \sim-51 \%$ と，はる加低低い值 示主。とのととは，後者は東北日本の白亜紀の花崫岩 の一連のものであるととを示し，前者はそれよりも古い 別の花崗岩であったととを示するのであろう。また，平 衡型でない效をるつ碞石仙，それぞれ捕獲岩であるか， 変成岩に直接接触する特別なものとして解积される。
} つがない。前者もは、平衡型と見るしてよいが，その 